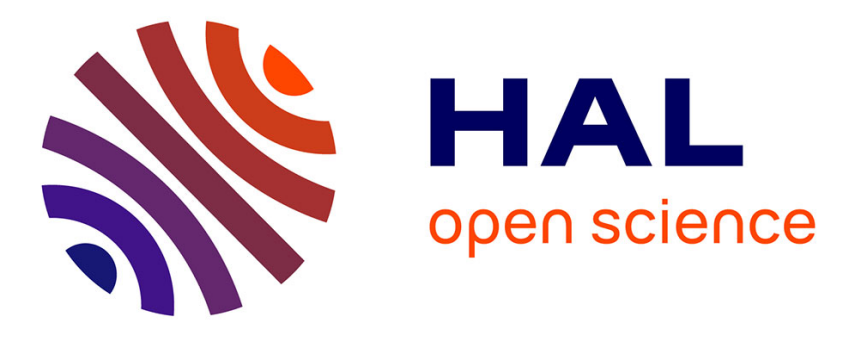

\title{
Dioscorea orangeana (Dioscoreaceae), a new and threatened species of edible yam from northern Madagascar
}

Paul Wilkin, Annette Hladik, Odile Weber, Claude Marcel Hladik, Vololoniaina Jeannoda

\section{To cite this version:}

Paul Wilkin, Annette Hladik, Odile Weber, Claude Marcel Hladik, Vololoniaina Jeannoda. Dioscorea orangeana (Dioscoreaceae), a new and threatened species of edible yam from northern Madagascar. Kew Bulletin, 2009, 64, pp.461-468. hal-00546781

\section{HAL Id: hal-00546781 https://hal.science/hal-00546781}

Submitted on 14 Dec 2010

HAL is a multi-disciplinary open access archive for the deposit and dissemination of scientific research documents, whether they are published or not. The documents may come from teaching and research institutions in France or abroad, or from public or private research centers.
L'archive ouverte pluridisciplinaire HAL, est destinée au dépôt et à la diffusion de documents scientifiques de niveau recherche, publiés ou non, émanant des établissements d'enseignement et de recherche français ou étrangers, des laboratoires publics ou privés. 


\section{Article publié en 2009 dans: Kew Bulletin, 64:461-468 \\ Dioscorea orangeana (Dioscoreaceae), a new and threatened species of edible yam from northern Madagascar}

\section{Paul Wilkin1, Annette Hladik2, Odile Weber1, Claude Marcel Hladik2 \& Vololoniana Jeannoda3}

Summary. A new species of yam (Dioscorea orangeana Wilkin) is described and illustrated. It differs from D. comorensis R.Knuth by having undulate leaf margins and a broader torus and tepals in both the male and female flowers. In female flowers of $D$. orangeana the floral stipe between the ovary and the torus is shorter than in D. comorensis. The tuber morphology of the species is atypical among Malagasy species in that there are several digitate lobes rather than a single tuber per growing season, although more research is needed on tuber morphology. D. orangeana is reported to be edible. It is endemic to the Forêt d'Orangea near Diego Suarez (Antsiranana) in Antsiranana Préfecture. Its conservation and sustainable use are thus matters of concern.

Key Words. Dioscoreaceae, Dioscorea, yams, Madagascar, new species, edible, conservation

Accepted for publication? Month 2008

${ }^{1}$ Royal Botanic Gardens, Kew, Richmond, Surrey TW9 3AB, U.K (author for correspondence:

p.wilkin@kew.org)

${ }^{2}$ UMR 5145 et USM 104, Éco-Anthropologie et Ethnobiologie, CNRS \& Muséum national d'Histoire naturelle, 4, Avenue du Petit Château, 91800 Brunoy, France.

${ }^{3}$ Département de Biologie et Ecologie Végétales, Faculté des Sciences, Université d'Antananarivo, BP 906, Antananarivo 101, Madagascar. 


\section{Introduction}

In 2003 the first author saw the specimen Humbert \& Cours 32277 at the Muséum national d'Histoire naturelle (MNHN) in Paris (P, see below for source of herbarium abbreviations), which had been collected in 1960 at the Forêt d'Orangea near Diego Suarez (Antsiranana) in Antsiranana Préfecture. It was unique among specimens of Dioscorea from Madagascar in possessing leaves with undulate margins, which are broad in relation to length, giving them a reniform appearance. Unfortunately the male flowers of this specimen are immature. No other specimens appear to have been collected between 1960 and June 2001, when Annette and Marcel Hladik collected leafless, fruiting material at the same locality, as Hladik 6621 (K, P). Since 2001 further specimens have been obtained; Rogers found both male and female flowering plants in 2003 (Rogers et al. 161 and 160 respectively, both at MO, P and TAN). Male and female fruiting specimens were obtained in 2004 by Marcel and Annette Hladik (Hladik 6828, 6829, 6830, 6835 and 6836, held at P). Male plants have also been collected by two other Missouri Botanical Garden (MO) collecting trips in 2003 annd 2005 (Miller et al. 10178 and Randrianaivo et al. 1148 respectively). A comparative study of these specimens and those of other Malagasy yams was therefore undertaken.

\section{Materials \& Methods}

The Yams of Madagascar Project comprises comparative morphological study and databasing of 1059 specimens from the following herbaria: B, BH, BM, BR, G, GH, GRA, K, MO, P, SNGF, TAN, TCD, TEF, WAG, UPS (abbreviations following Index Herbariorum, http://sciweb.nybg.org/science2/ IndexHerbariorum.asp). The specimens used in the study of $D$. orangeana are cited below. Floral dissections were carried out where appropriate and measurements made using a Leica MZ95 or Carl Zeiss microscope with a measuring eyepiece. Vegetative and inflorescence characters were measured with a dial caliper. The distribution map and conservation status assessment were prepared using ArcView 3.3 as part of a larger study of the conservation status of Dioscorea in Madagascar (Wilkin et al., unpublished data).

\section{Results}

Comparative morpological study of the new material confirms that it is a species that was not included in the Flore de Madagascar treatment (Burkill \& Perrier 1950). It is morphologically distinct from all other Dioscorea species in Madagascar in its underground, above-ground vegetative and reproductive organs. It most closely resembles $D$. comorensis R. Knuth, an endemic of the Comoro Archipelago (Wilkin et al. 2007), from which it differs by having undulate leaf margins and a broader torus and tepals in both the male and female flowers. In female flowers of $D$. orangeana the floral stipe between the ovary and the torus is 
shorter than in D. comorensis. These differences are summarised in Table 1. This taxon is thus described below as a new species for Madagascar.

\section{Taxonomic Description}

Dioscorea orangeana Wilkin, sp. nov., D. comorensi R.Knuth affinis sed planta glabra, foliis ad marginem plerumque undulatis, florum masculorum toro $1.3-2.6 \mathrm{~mm}$ (nec $0.8-1.5 \mathrm{~mm}$ ) lato tepalis exterioris 1.0 - $1.6 \mathrm{~mm}$ (nec $0.4-1.1$ ) latis ovatis vel late ellipticis (nec lanceolatis neque ellipticis neque ellipticooblongis neque anguste elliptico-oblongis), tepalis interoris $1.2-2.1 \mathrm{~mm}$ (nec $0.8-1.3 \mathrm{~mm}$ ) latis latissime ovatis vel latissime ovato-orbiculatis vel latissime ovato-oblongis (nec elliptico-oblongis neque ovatis neque late ovatis), florum femineorum stipite florali $0.2-0.5$ (nec $0.4-0.8 \mathrm{~mm}$ ) longo, tepalis exterioris $1-1.2$ $\mathrm{mm}$ (nec $0.5-0.8 \mathrm{~mm}$ ) latis ovatis vel late ovatis (nec ellipticis neque elliptico-oblongis neque lanceolatis), tepalis interioris $1.2-1.8 \mathrm{~mm}(\mathrm{nec}(0.6-) 0.8-1.1 \mathrm{~mm})$ latis latissime ovatis vel ovato-orbiculatis vel oblongo-orbiculatis (nec ellipticis neque elliptico-oblongis neque late elliptico-oblongis) differt. Typus: Madagascar. Orangea, about $1.5 \mathrm{~km}$ NE of Military Camp 'Orangea', on sandy road along trail to ocean, $\hat{\sigma}$ fl. 15 Feb. 2003, Rogers, Rakotonasolo \& Vigneau 161 (holotypus P!; isotypi MO!, TAN). Figs 1, 2.

A twining vine to no more than $5 \mathrm{~m}$, stems annual from a fleshy tuber. Tuber to c. $20 \mathrm{~cm}$ in diam., apically dome-shaped, with several digitate young growths below (Fig. 2H), epidermis pale to dark brown (latter in older parts), parenchyma creamy white. Indumentum wholly absent, even from axillary buds. Stems left-twining, to c. $5 \mathrm{~mm}$ in diameter, quite woody, nodes swollen towards base above and below ground, in soil descending vertically, with a white, roughened epidermis, producing thick roots at nodes, above ground bearing small brown prickles at extreme base, grey-brown, towards base with longitudinal ridges and channels between them when dry, distal shoots terete with weak longitudinal ridges, unarmed, pale green when fresh. Leaves (Fig. 1A) alternate, blade $17-68 \times 12-65 \mathrm{~mm}$, ovate to ovate-deltoid or ovatesagittate, sometimes broadly ovate-orbicular, broadly ovate-reniform or orbicular-reniform, main stem leaves tending to be broader, chartaceous to thinly so, juvenile leaves often variegated by possessing an ovate to elliptic, cream to pale yellow or pale green splash with irregularly toothed margins extending from the point of petiole insertion, mid green above, paler and glossy below, drying dull olive-green, slightly paler below, sometimes with a few black glands (like those of e.g. D. trichantha Baker or D. seriflora Jum. \& H.Perr.) scattered near the point of petiole insertion, glossy, circular to oval, with an annulus around the outside, less visible on upper surface where they lack an annulus and are less clearly defined; margins usually entire and undulate (e.g. apical leaf of Fig. 1A, more easily seen in living plants), sometimes also 
weakly lobed towards stem base; basal sinus 0.5 - $19 \mathrm{~mm}$ deep, weakly and broadly cordate to narrowly so, subhippocrepiform or with inner margins of basal lobes overlapping and sinus very narrow; apex 1.4 - $15 \mathrm{~mm}$ long, acuminate to long-acuminate, with a c. $0.5-4.5 \mathrm{~mm}$ long, narrowly deltoid, dark brown forerunner tip, or in broadly ovate-reniform leaves with rounded or truncate apices the acumen consists only of the forerunner tip, veins 5, only 3 reaching apex in smaller leaves with a smaller, often bifid, vein to each basal lobe, primary venation prominent on lower leaf blade surfaces; petiole $11-72 \mathrm{~mm}$ long, \pm terete with longitudinal ridges and channels like stem when dry, with a broader channel on upper surface, basal and apical pulvinus drying darker, but paler green in fresh material, petiole base expanded and deltoid where it is inserted on to node, especially on lower stems, appearing homologous with cataphylls at stem base; lateral nodal organs (“stipules" of Burkill (1960) present as a pair of fleshy, obtuse projections on either side of node; cataphylls present towards stem base, to c. $5 \mathrm{~mm}$ long, broadly to very broadly ovate, base clasping stem, apex acuminate, drying dark brown; bulbils (only produced in the axils of plants cultivated by Annette Hladik), pale brown, elongate-cylindrical but rather irregular, warty. Male inflorescences 1-2 per axil, pendent, racemose, simple or compound through suppression of leaves in axillary shoots, where compound sterile base of primary axis c. $10 \mathrm{~mm}$ long, fertile part shorter (Fig. 1C), both flattened and winged like partial inflorescence axis, colour as stem; partial inflorescence bracts c. $1.5 \mathrm{~mm}$ long, ovate to narrowly so, acuminate, membranous, with a thicker midrib; partial inflorescence peduncle $5-18 \mathrm{~mm}$ long, axis $(6.5$ - )33- $155 \times 0.5-1.2 \mathrm{~mm}$, flattened and winged, wing widest at nodes; flowers in cymules of $(1-) 2-4$ (Fig. 1D), cymules $0.5-6(-11) \mathrm{mm}$ apart, regularly to irregularly spaced, sometimes very dense towards apex where axis elongation appears to have failed or subopposite elsewhere, cymule bracts 1 per node, 1.1 $-2.1 \mathrm{~mm}$ long, narrowly ovate to elliptic, acuminate to long-acuminate, membranous, with a thicker midrib, cymule primary branch $0.1-1 \mathrm{~mm}$ long. Female inflorescences to c. $18 \mathrm{~cm}$ long, simple, spicate, pendent, axis flattened and winged like male, colour as stem. Male flowers lime-green to yellow-green, scent not recorded, pedicellate, floral bract at pedicel base $0.8-1.7 \times 0.2-0.8 \mathrm{~mm}$, narrowly ovate to lanceolate, acuminate, membranous, with a thicker midrib; pedicels $1-2.1 \times 0.2-0.6 \mathrm{~mm}$, narrowly obdeltoid in outline; tepals differentiated into 2 whorls of 3, (inner broader, Fig. 1E), membranous with a thicker midrib, both whorls inserted on a shallow, open, saucer- to bowl-shaped torus $0.3-1.2 \times 1.3-2.6 \mathrm{~mm}$ (Fig. $1 \mathrm{G}$ ), membranous and semi-translucent like tepals, abruptly thickened towards centre where filaments are inserted (perhaps only thickened part is true torus and the rest fused tepals); tepals erect in bud, \pm patent to torus margin (i.e. spreading) at anthesis, outer whorl $1.2-1.9 \times 1-1.6 \mathrm{~mm}$, ovate to broadly elliptic, apex acute to acuminate, inner whorl $1.2-2 \times 1.2-2.1 \mathrm{~mm}$, very broadly ovate to very broadly ovate-orbicular or very broadly ovate-oblong, apex obtuse to acute; stamens inserted in a ring on a thickened area in the 
torus centre, filaments $0.3-1.2 \mathrm{~mm}$ long, erect at base, free and reflexed in an arching manner towards apex so that anthers face basal half of filament (Fig. 1F) and are held roughly half way between torus centre and rim (Fig. 1G), anthers $0.15-0.45 \times 0.15-0.35 \mathrm{~mm}$, basifixed, yellow; pistillode if present concealed by anthers. Female flowers lime-green, (sub)sessile until capsule development begins, scent not recorded; floral bract $1.2-1.5 \times 0.5-1 \mathrm{~mm}$, elliptic to ovate or broadly so, acuminate to long-acuminate, membranous, with a thickened midrib, bracteole like bract but shorter, narrower and inserted at $90^{\circ}$ to it (Fig. 2B); ovary c. $4.6-6.6 \mathrm{~mm}$ long, 3-angled, oblong to narrowly elliptic-oblong in outline, green, apex acute to obtuse; floral stipe (between ovary and torus, Fig. 2B) $0.2-0.5 \mathrm{~mm}$ long; tepals spreading at anthesis, differentiated into 2 whorls of 3 , thickly membranous, with a thicker midrib, inserted on the rim of a $0.5-0.7 \times 1.3-1.6$ $\mathrm{mm}$, open, saucer- to shallowly bowl-shaped torus, texture like tepals but thickening gradually towards style bases; outer tepals $1.4-1.6 \times 1-1.2 \mathrm{~mm}$, ovate to broadly so, apex acute to acuminate; inner tepals 1.2 $-1.8 \times 1.2-1.8 \mathrm{~mm}$, very broadly ovate to ovate-orbicular or oblong-orbicular, apex obtuse to rounded; staminodia $6,0.3-0.6 \mathrm{~mm}$ long, inserted around the style base near the most sharply curved part of torus (Fig. 2C, D), erect, filiform with a capitate, erect to recurved apex in which the upper antheriform part consists of more translucent tissue; styles $0.9-1.2 \mathrm{~mm}$ long, fused to form an erect column for c. $0.7 \mathrm{~mm}$, apices free, recurved, bifid, bearing 2 deltoid, horn-like stigmas c. $0.5 \mathrm{~mm}$ long, spreading and borne patent to the style branch (Fig. 2D). Capsule ascending at c. $45-5^{\circ}$ to axis at dehiscence (Fig. 2E) on a clavate, angled capsular stipe to $2.5 \mathrm{~mm}$ long, $19-29 \times 10-12 \mathrm{~mm}$, oblong to narrowly so, base shallowly retuse to rounded, apex shallowly retuse to acute, margin separating as an opercular strip (Fig. 2F), tepal bases or floral stipe usually persistent as an apiculus on each lobe of capsule, opening to more than half length to release seeds, pale brown with chestnut-brown flecking. Seeds winged at base only (Fig. $2 \mathrm{G}), 4.8-6.5 \times 3.8$ - 4.2 mm excluding wing, ovoid-lenticular to flattened ovoid-reniform, matt dark brown, wing $8.4-10.5$ $\times 4.3-6.2 \mathrm{~mm}$, narrowly to broadly oblong, apex obtuse to rounded, membranous, golden-brown with slightly darker flecking.

DISTRIBUTION. Found only in the Forêt d'Orangea near Antsiranana in Northern Madagascar. MADAGASCAR. Antsiranana, Forêt d'Orangea, đ̂ fl. buds 22 Jan. 1960 Humbert \& Cours 32277 (P); Forêt d'Orangea, Camp Militaire, ổ fl. 1 Feb. 2004 Hladik 6830 (P); Forêt d'Orangea, Camp Militaire, §̂ fl. 1 Feb. 2004, Hladik 6836 (P); Forêt d'Orangea, Camp Militaire, đ̊ fl. 1 Feb. 2004, Hladik 6835 (P); Forêt d'Orangea, Camp Militaire, sterile 1 Feb. 2004, Hladik 6828 (P); Forêt d'Orangea, Camp Militaire, sterile 1 Feb. 2004 Hladik 6829 (P); Forêt d'Orangea, Camp Militaire, ๆ fr. 14 June 2001, Hladik 6621 (K, P) and specimen grown from its seed, sterile with bulbils, Hladik 6621A (P); Orangea, about $1.5 \mathrm{~km} \mathrm{NE} \mathrm{of}$ 
Military Camp 'Orangea', on sandy road along trail to ocean, $12^{\circ} 14^{\prime} 18^{\prime}$ S $49^{\circ} 21^{\prime}$ '49” E $q$ fl. \& immature fr. 15 Feb. 2003, Rogers, Rakotonasolo \& Vigneau 160 (MO, P, TAN); Forêt d'Orangea, along the dirt track near the remains of the French fort on the hill above Ramena, $12^{\circ} 15^{\prime} 01^{\prime \prime} \mathrm{S} 49^{\circ} 21^{\prime} 39^{\prime \prime} \mathrm{E}, \mathrm{o}^{\prime} \mathrm{fl}$. and fl. buds 20 Jan. 2003, Miller, Applequist, Rabenantoandro \& Ranaivojaona 10718 (MO); Diego II, Ramena, Forêt

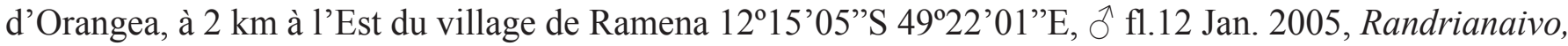
Rakotonandrasana, Rakotondrajaona, Guittou \& Benjara 1148 (MO)

VERNACULAR NAME. Angona (Antakarana, Sakalava, Forêt d'Orangea). However, more than one wild yam species appears to be known as Angona in the Antsiranana region.

ECOLOGY. Found in deciduous forest on sand at altitudes not exceeding $100 \mathrm{~m}$.

PHENOLOGY. Flowering in January and February, fruit developing thereafter, dehiscing in June.

CONSERVATION STATUS. Figs 3 and 4 show the distribution of this species in Northern Madagascar through georeferencing the specimens cited above. The extent of occupancy (EOO) of $D$. orangeana is $3.6 \mathrm{~km}^{2}$, and its area of occurrence is $1.7 \mathrm{~km}^{2}$ using a cell size of $0.58 \mathrm{~km}^{2}$; it occupies five cells. Both of these measures suggest that the appropriate IUCN red list assessment is CR. In December $2002 \mathrm{CMH}$ found a tuber on a sterile plant in a transect at $12^{\circ} 16^{\prime} 45.0^{\prime \prime S} 49^{\circ} 23^{\prime} 41.3$ ” E, near Andovokonko, c. $10 \mathrm{~km}$ South-east of Ramena, which matched the form found in Hladik 6828. Should this locality prove to hold D. orangeana, it would extend the range of the species outside the Forêt d'Orangea and increase the EOO and AOO. There is also a significant area of dry forest north of Antsiranana, in the northernmost part of Madagascar. This region is botanically poorly known, but may provide suitable habitat for D. orangeana. However, in the absence of further specimens clearly belonging to D. orangeana we suggest a provisional IUCN red list assessment of CR B1ab(iii); B2ab(iii).

D. orangeana is reported to be abundant in the Forêt d'Orangea, but the tubers are thought to be extracted in large quantities: $\mathrm{AH}$ and CMH saw a large number of "yam holes" in the Forêt d'Orangea. It appears that all of the yams known as Angona in the Antsiranana region are favoured edible species and thus heavily exploited. As Fig. 4 shows, the Forêt d'Orangea is not protected, and the nearest such area is at least $20 \mathrm{~km}$ away.

USES. Tuber edible.

ETYMOLOGY. The vernacular name Angona is also applied to D. sambiranensis R.Knuth (Burkill \& Perrier 1950) amongst other species. Thus the epithet orangeana was chosen to reflect the endemic distribution of the species in the Forêt d'Orangea.

NOTES. D. orangeana differs from all other species of Dioscorea in Madagascar by usually 
possessing leaves with undulate margins. The variegated juvenile leaves may also be a useful spot character. Of the other differences between D. orangeana and D. comorensis (Table 1) most are discrete. In some, such as tepal width, there is a small range overlap between the two species. They are clearly different in shape, however, with $D$. orangeana having broader tepals in both whorls. In both species, the inner whorl of tepals is broader than the outer. It also appears that the seeds and capsules of D. orangeana are narrower than those of D. comorensis, but for both species the measurements are based on just one known fruiting specimen.

Both the male and female flowers of D. orangeana have saucer- to bowl-shaped, relatively open tori like D. sterilis Weber \& Wilkin and D. decaryana H.Perr., but the torus is semi-translucent and tepal-like in texture, not thicker and opaque as in those species. The torus of D. orangeana is less deep and more open than those species with campanulate tori (Wilkin et al., in press). In the remaining species in Madasgacar and the Comoro Archipelago, the tori are differently shaped, but they are all thicker than the tepals and opaque in dried and fresh specimens.

\section{Tuber morphology}

The unusual tuber of this species (Fig. 2H) was observed by AH in both plants in the field and in young plants grown from seed taken from Hladik 6621. However, VJ found only yams with one vertically oriented tuber per growing season in sterile plants of unknown species during field study around Antsiranana in August 2006. It remains possible that this organ is polymorphic in D. orangeana; more research is needed. One vertically oriented (at least at its point of attachment to the crown) tuber per growing season is the most common condition in Madagascar and the Comoros. More rarely, some species possess several narrow, cylindric, laterally spreading tubers with thickened apices (e.g. D. bemarivensis Jum. \& H.Perr, D. proteiformis H.Perr.). The tuber of $D$. comorensis falls into the former category, based on a photograph of the tuber of a plant from near Itsamia Ngouni on Mwali (Daan Ouni Msoili, pers. comm).

\section{Acknowledgements}

The COLPARSYST programme provided financial support for a visit by PW to the Museum National d'Histoire Naturelle in Paris in October 2003, and the SYNTHESYS programme a further visit in October 2006; he would like to thank Leandro Leoz and all the staff of the Laboratoire de Phanerogamie for their help, especially Jean-Noel Labat and Thierry Deroin. Thanks are also due to the MADSUP programme which funded research undertaken by the Département de Biologie et Ecologie Végétales on Yams in the Antsiranana area. Jim Solomon helped to get access to specimens and Lucy Smith produced the excellent Figures. Dave Simpson's constructive comments improved an earlier version of this manuscript. Odile 
Weber and Melanie Thomas translated the Latin diagnosis. Thanks are also due to Jean-Noel Labat, Nicole

Crestey and Daan Ouni Msoili for collecting specimens and/or photographing D. comorensis.

\section{References}

Burkill, I.H. (1960). The organography and the evolution of the Dioscoreaceae, the family of the yams. $J$. Linn. Soc. (Bot.) 56: 319-412.

Burkill, I.H. \& Perrier, H. (1950). Dioscoréacées. In: H. Humbert (Ed.), Flore de Madagascar et des Comores. Muséum national d'Histoire naturelle, Paris.

IUCN. (2001). IUCN Red List Categories: Version 3.1. Prepared by the IUCN Species Survival Commission. IUCN, Gland, Switzerland \& Cambridge, UK.

Wilkin, P., Hladik, A., Labat, J.-N. \& Barthelat, F. (2007). A new edible yam (Dioscorea L.) species endemic to Mayotte, new data on D. comorensis R.Knuth and a key to the yams of the Comoro Archipelago. Adansonia, sér. 3, 29(2): 215 - 228

Wilkin, P, Andrianantenaina, W.P, Jeannoda, V. \& Hladik, A. (in press). The species of Dioscorea L. (Dioscoreaceae) from Madagascar with campanulate tori, including a new species from Eastern Madagascar. Kew Bulletin 62: 000-000.

Wilkin, P., Jeannoda, V., Hladik, A., Weber, O. \& Moat, J. (unpublished data). The conservation status of the yam species of Madagascar: which speces are threatened? 


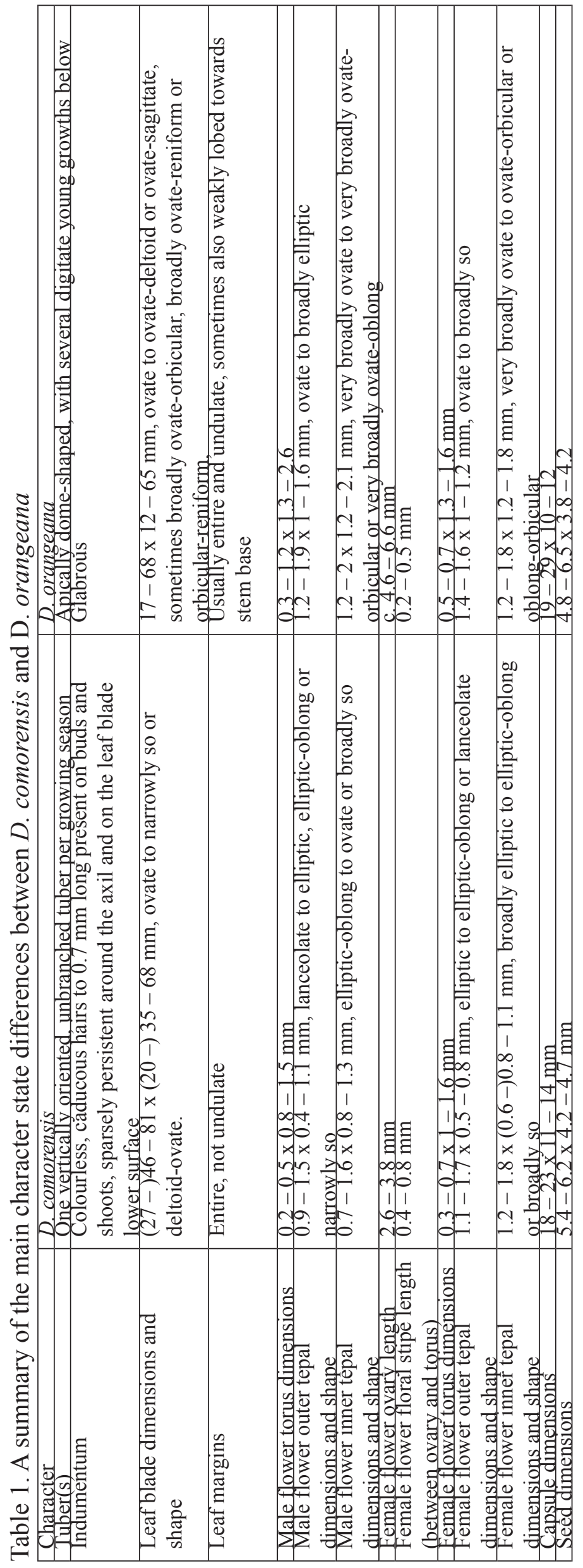




\section{Captions}

Fig. 1. Dioscorea orangeana habit, male inflorescences and flowers

A. Habit, stem and simple axillary inforescences with flowers at the bud stage. The apical leaf shows its undulate margin most clearly. Scale bar $=2 \mathrm{~cm}$.

B. A node with a simple axillary inflorescence bearing flowers at anthesis. Scale bar $=2 \mathrm{~cm}$.

C. A node with a leaf and a basally branching compound inflorescence bearing flowers at anthesis. Scale bar $=2 \mathrm{~cm}$.

D. A cymule showing an open flower at anthesis and two buds. Scale bar $=2.5 \mathrm{~mm}$.

E. A flower (top view) showing the tepals (inner whorl broader), torus and position of the stamens. Scale bar $=2.5 \mathrm{~mm}$.

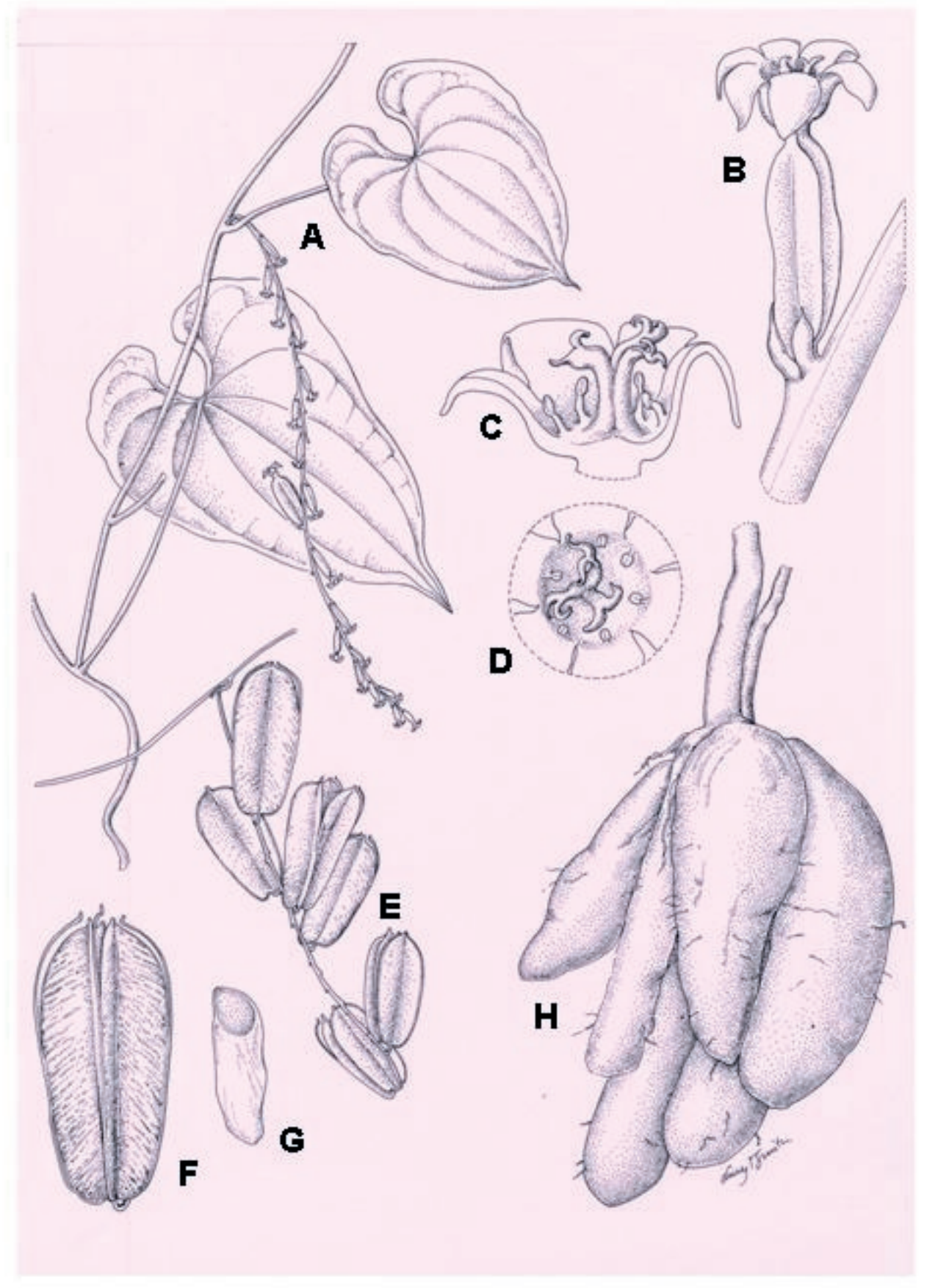


F. The stamens with the torus and tepals cut away, showing their habit due to the recurvature of the filaments. Scale bar $=1.2 \mathrm{~mm}$.

G. A half-flower (longitudinal section) showing the shape of the torus, the insertion of the tepals onto it, and the insertion of the stamens. Scale bar $=1.2 \mathrm{~mm}$. Drawn from Humbert \& Cours 33227 (A) and Rogers et al. 161 (B - G). DRAWN BY LUCY SMITH.

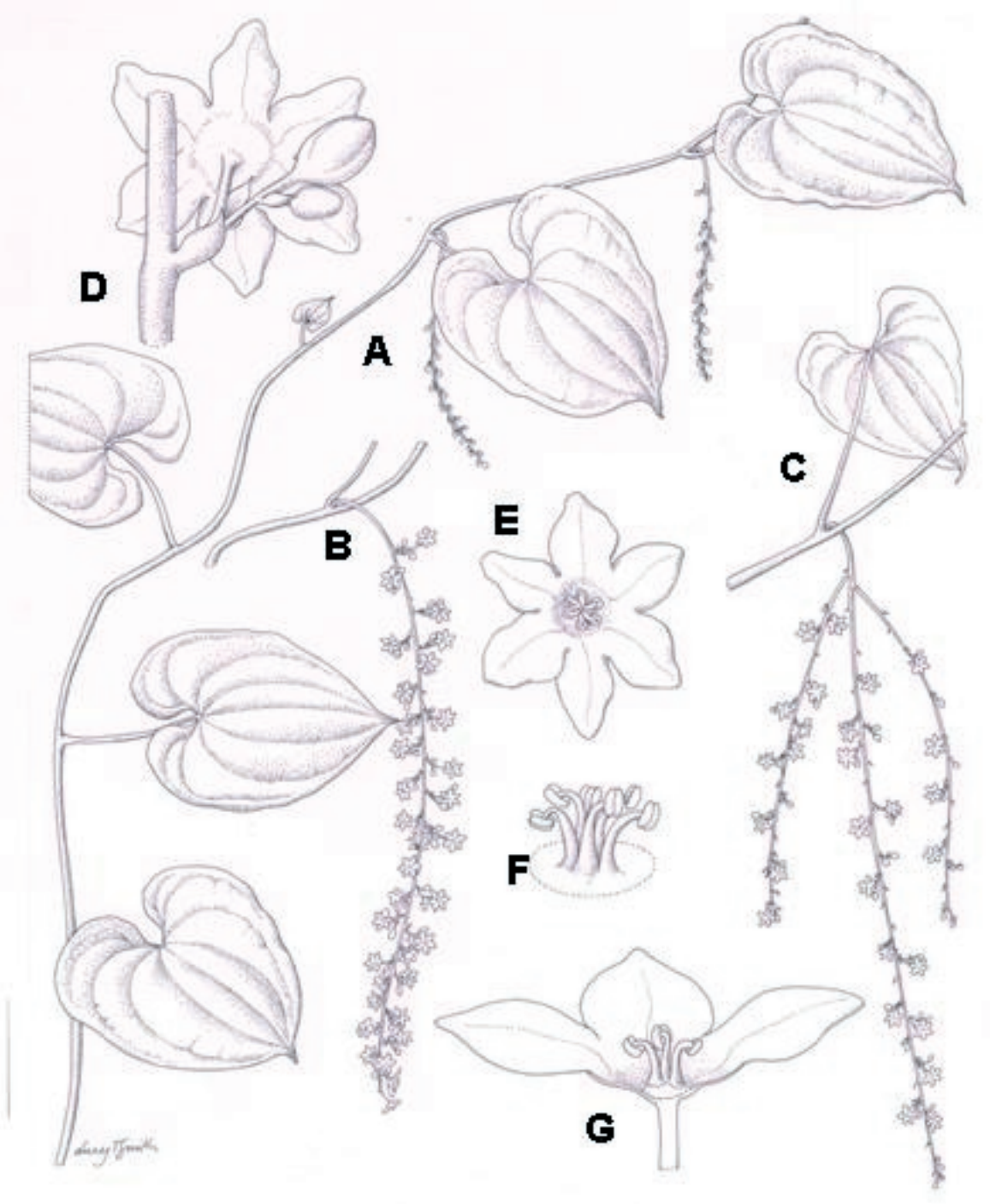

Fig. 2. Dioscorea orangeana female inflorescences, flowers and fruit.

A. Habit, stem and inflorescence with flowers at anthesis and in the early stages of capsule development (reflexed). Scale bar $=2 \mathrm{~cm}$.

B. Flower, showing floral bract and bracteole, developing ovary and stipe between ovary apex and torus. Scale bar $=2.5 \mathrm{~mm}$.

C. Half-flower (longitudinal section), showing torus shape, staminodia, styles and stigmas. Scale bar $=1.4$ mm.

D. Top view of the torus showing the insertion of the staminodia and position of the stigmas. Scale bar $=1.7$ mm. 
E. Infructescence at dehiscence. Scale bar $=1.5 \mathrm{~cm}$.

F. Capsule at dehiscence. Scale bar $=1 \mathrm{~cm}$.

G. Basally winged seed. Scale bar $=1 \mathrm{~cm}$.

H. Tuber, crown and stem base. Scale bar $=5 \mathrm{~cm}$.

Drawn from Rogers et al. 160 (A - D), Hladik 6621 (E - G) and a photograph of the tuber of Hladik 6828. DRAWN BY LUCY SMITH.

Fig. 3. A map of Madagascar showing the location of the Forêt d'Orangea east of Antsiranana where all existing collections of $D$. orangeana have been made.

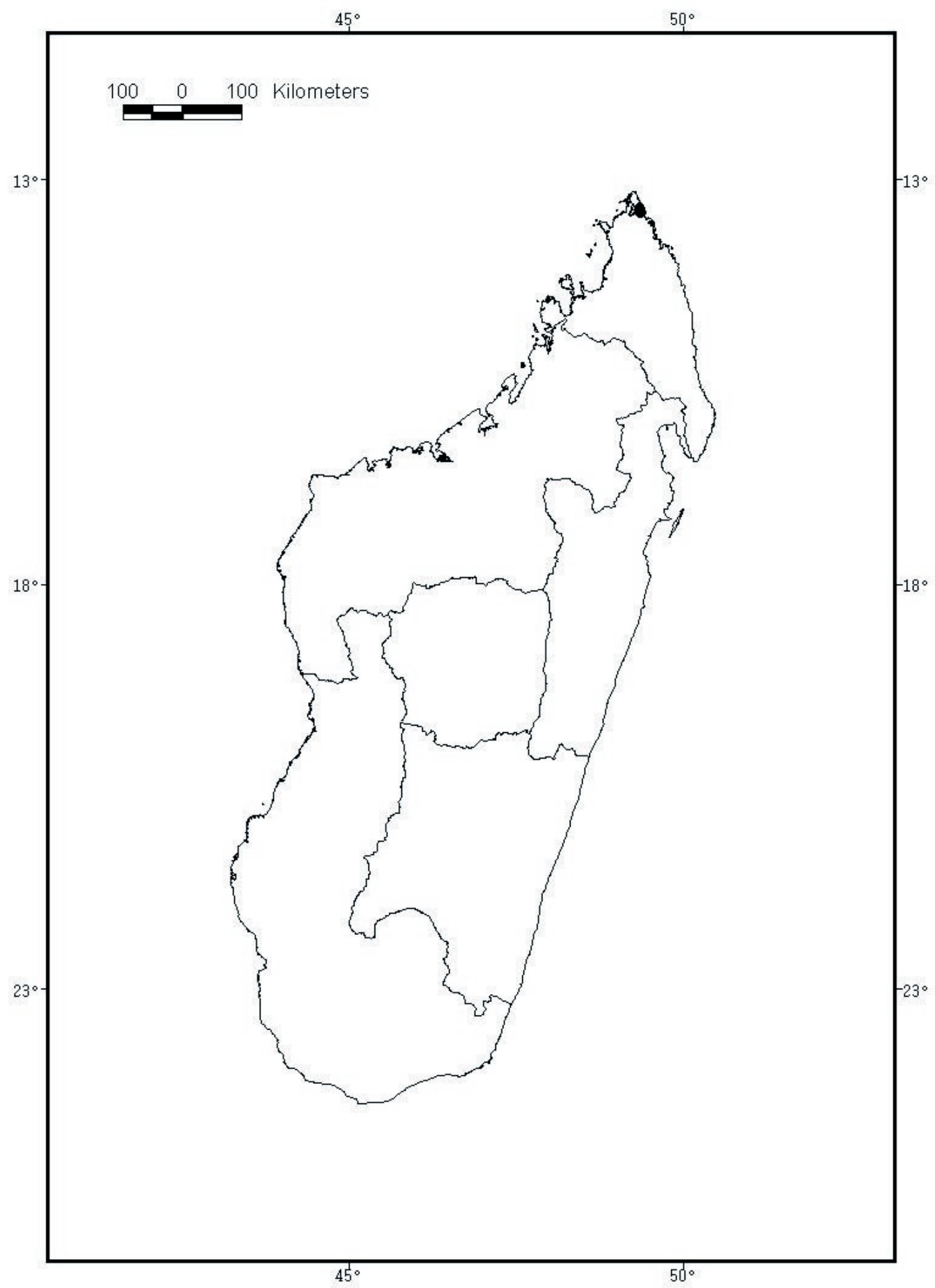


Fig. 4. A larger scale map of the northern tip of Madagascar showing the locations of the existing collections of D. orangeana near Ramena. The city of Antsiranana and the highest point of the Montagne des Français are indicated, and the nearest protected areas are shaded.Fig. 1.

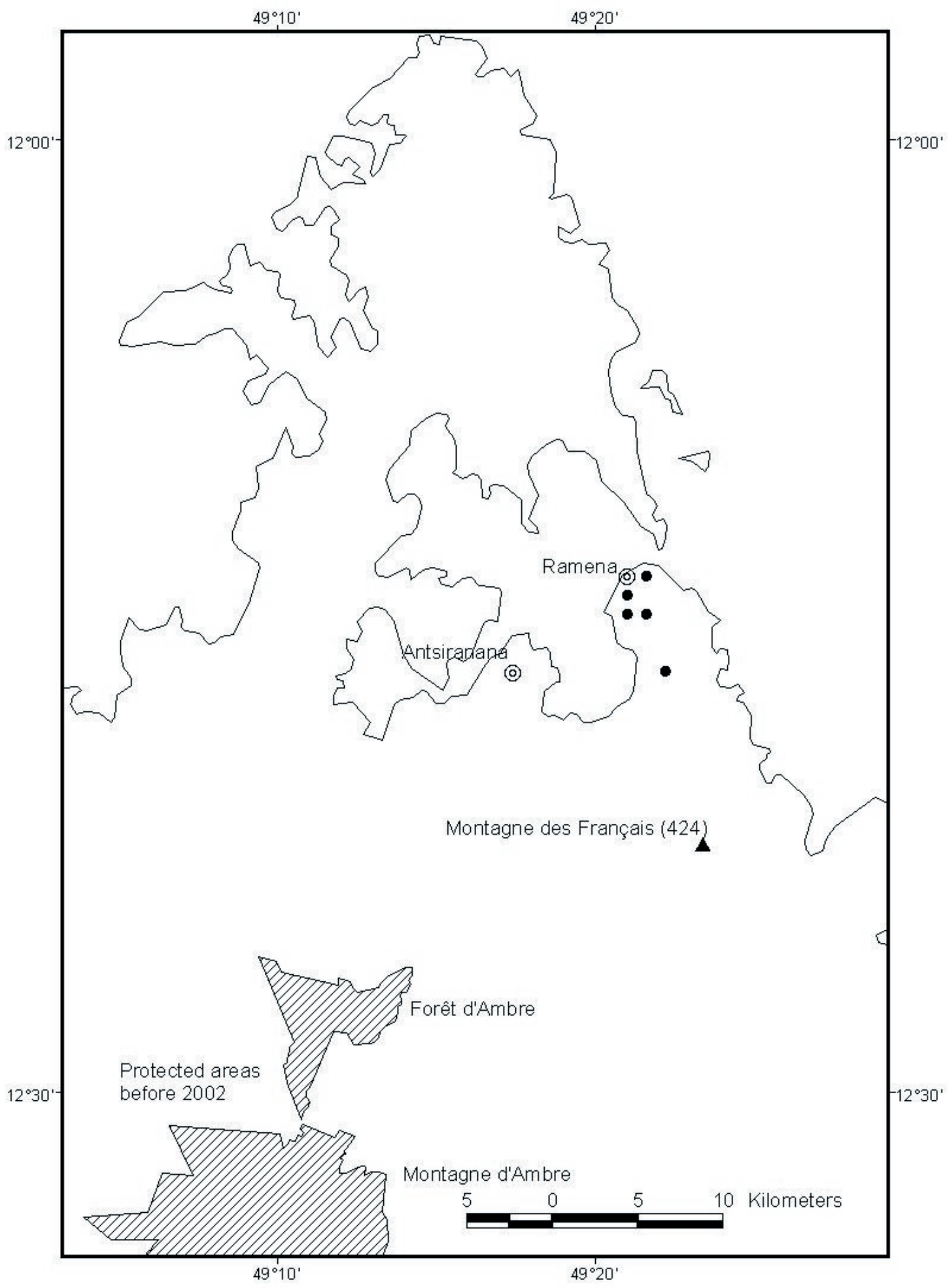

